\title{
Net primary production of terrestrial ecosystems from 2000 to 2009
}

\author{
Christopher Potter • Steven Klooster • Vanessa Genovese
}

Received: 7 May 2011 / Accepted: 23 March 2012

(C) The Author(s) 2012. This article is published with open access at Springerlink.com

\begin{abstract}
The CASA (Carnegie-Ames-Stanford) ecosystem model has been used to estimate monthly carbon fluxes in terrestrial ecosystems from 2000 to 2009, with global data inputs from NASA's Terra Moderate Resolution Imaging Spectroradiometer (MODIS) vegetation cover mapping. Net primary production (NPP) flux for atmospheric carbon dioxide has varied slightly from year-to-year, but was predicted to have increased over short multi-year periods in the regions of the high-latitude Northern Hemisphere, South Asia, Central Africa, and the western Amazon since the year 2000. These CASA results for global NPP were found to be in contrast to other recently published modeling trends for terrestrial NPP with high sensitivity to regional drying patterns. Nonetheless, periodic declines in regional NPP were predicted by CASA for the southern and western Untied States, the southern Amazon, and southern and eastern Africa. NPP in tropical forest zones was examined in greater detail to discover lower annual production values than previously reported in many global models across the tropical rainforest zones, likely due to the enhanced detection of lower production ecosystems replacing primary rainforest.
\end{abstract}

\section{Introduction}

Net photosynthetic accumulation of carbon by plants, also known as net primary production (NPP), provides the energy that drives most biotic processes on Earth. NPP represents much of the organic matter that is consumed by microbes and animals. Climate controls on NPP fluxes are an issue of central relevance to society, mainly because of concerns about the extent to which NPP in managed ecosystems can provide adequate food and fiber for a growing human population.

Previously published estimates of global NPP (Potter et al., 2003, 2009; Nemani et al. 2003) imply that above-average global temperatures were commonly associated with an

C. Potter $(\square)$

NASA Ames Research Center, Moffett Field, CA, USA

e-mail: chris.potter@nasa.gov

S. Klooster $\cdot$ V. Genovese

California State University Monterey Bay, Seaside, CA, USA 
increasing trend in terrestrial ecosystem sinks for atmospheric $\mathrm{CO}_{2}$ between the years 1982 and 1999. These predictions support the hypothesis that regional climate warming has had relatively small-scale positive impacts on atmospheric $\mathrm{CO}_{2}$ sequestration rates, particularly in northern high latitude ecosystems (tundra and boreal forest). In the low latitude zones dominated by rainforests, the modeling results support the hypothesis that both sunlight and precipitation remain co-limitations to long-term NPP patterns. The trend in global terrestrial NPP since the year 1999 has become a subject of debate, with evidence to suggest a periodic downward trajectory linked to large-scale warming and drying in the Southern Hemisphere that counteracted increased NPP over the Northern Hemisphere (Zhao and Running, 2010).

Direct input of satellite vegetation index "greenness" data from the MODIS sensor into ecosystem simulation models can be used to estimate spatial variability in monthly NPP, plant biomass accumulation, and litter fall inputs to soil carbon pools (Potter et al., 1993, 2009). Global NPP of vegetation is predicted using the relationship between greenness reflectance properties and the fraction of absorption of photosynthetically active radiation (fPAR), assuming that net conversion efficiencies of PAR to plant carbon can be approximated for different ecosystems or are nearly constant across all ecosystems (Nemani and Running, 1989; Sellers et al., 1994; Goetz and Prince, 1998; Running and Nemani, 1998). For this study, we used MODIS collection 5 of the Enhanced Vegetation Index (EVI; Huete, et al., 2002, 2006) as an improvement in the model inputs for PAR interception, aggregated to $0.5^{\circ}$ (latitude/longitude) spatial resolution.

The CASA (Carnegie-Ames-Stanford) ecosystem model described in this study predicts NPP and terrestrial carbon balance on a global scale (Potter et al., 1993, 2009). MODIS EVI data were direct input drivers for CASA. The purpose of this paper was to validate and report the patterns of regional variations in NPP in response to climate anomalies and extremes over the years 2000 to 2009 .

\section{Modeling methods}

Interannual NPP fluxes from the CASA model have been reported previously (Behrenfeld et al., 2001) and validated against multi-year estimates of NPP from field stations and tree rings (Malmström et al., 1997). Net ecosystem fluxes of carbon from CASA have been validated against atmospheric inverse model estimates over two decades (Potter et al., 2003).

As documented in Potter (1999), the monthly NPP flux, defined as net fixation of $\mathrm{CO}_{2}$ by vegetation, is computed in CASA on the basis of light-use efficiency (Monteith, 1972). Monthly production of plant biomass is estimated as a product of time-varying surface solar irradiance, $\mathrm{S}_{\mathrm{r}}$, and EVI from the MODIS sensor, plus a constant light utilization efficiency term $\left(\mathrm{e}_{\max }\right)$ that is modified by time-varying stress scalar terms for temperature $(\mathrm{T})$ and moisture (W) effects (Eq. 1).

$$
\mathrm{NPP}=\mathrm{S}_{\mathrm{r}} \mathrm{EVI} \mathrm{e}_{\max } \mathrm{TW}
$$

The CASA $\mathrm{e}_{\max }$ term was set uniformly at $0.55 \mathrm{gC} \mathrm{MJ}^{-1} \mathrm{PAR}$, a value that derives from calibration of predicted annual NPP to previous field estimates (Potter et al., 2003). This model calibration has been calibrated globally by comparing predicted annual NPP to more than 1900 field measurements of NPP (Potter et al., 2003). Climate drivers for the CASA model were from the National Center for Environmental Prediction (NCEP) DOE-II reanalysis data set (Zhao and Running, 2010). NCEP land surface temperature, precipitation rates, and surface solar radiation data sets were averaged to monthly values at the $0.5^{\circ}$ cell size. 
Land cover settings were aggregated from the MODIS global 1-km product (Zhao and Running, 2010).

The global $0.5^{\circ}$ resolution MODIS vegetation index (VI) data sets used as inputs to Eq. 1 were generated by aggregating monthly $0.05^{\circ}(\sim 6 \mathrm{~km})$ data (MOD13C2 version 005$)$ from the USGS Land Processes data center (LP DAAC). The VI layer was selected from each MOD13C2 spatial composite file and surface water values are converted to "NoData". To aggregate from a $0.05^{\circ}$ cell size to $0.5^{\circ}$, the VI values for each $10 \times 10$ pixel block were then averaged to create a single $0.5^{\circ}$ pixel greenness value. Each monthly layer was then multiplied by 0.0001 to scale the data to the standard MODIS VI value range. This aggregation procedure provided the greatest assurance of high-quality, cloud-free VI inputs to the carbon cycle model. The MOD13C2 gap-filling and temporal smoothing procedures are commonly accepted methods for unifying multi-year satellite VI data sets in cloudy regions (Jönsson and Eklundh, 2004). In order to calculate annual CASA NPP, these procedures must be applied to fill cloud- (or aerosol-) contaminated observations, since plant photosynthesis continues during daylight hours regardless of cloud cover (Zhao and Running, 2011).

The $\mathrm{T}$ stress scalar in Eq. 1 was computed with reference to derivation of optimal temperatures $\left(\mathrm{T}_{\mathrm{opt}}\right)$ for plant production. The $\mathrm{T}_{\mathrm{opt}}$ setting will vary by latitude and longitude, ranging from just above $0^{\circ} \mathrm{C}$ in the Arctic to the middle thirties in low latitude deserts. The W stress scalar was estimated from monthly water deficits, based on a comparison of moisture supply (precipitation and stored soil water) to potential evapotranspiration (PET) demand using the method of Priestly and Taylor (1972).

Evapotranspiration was connected to water content in the soil profile layers, according to algorithms described by Potter (1999). The soil model design includes three-layer heat and moisture content computations: surface organic matter, topsoil $(0.3 \mathrm{~m})$, and subsoil to rooting depth (1 to $10 \mathrm{~m}$ ). Maximum rooting depth for cropland and grassland cover types was set at $1 \mathrm{~m}$, whereas non-tropical forest was set at $2 \mathrm{~m}$ and tropical forest was set at $10 \mathrm{~m}$ (Potter et al, 2003). These layers can differ in soil texture, moisture holding capacity, and carbon-nitrogen dynamics. Water balance in the soil was modeled as the difference between precipitation or volumetric percolation inputs, monthly estimates of PET, and the drainage output for each layer. Inputs from rainfall can recharge the soil layers to field capacity. Excess water percolates through to lower layers and may eventually leave the system as seepage and runoff.

The CASA model's seasonal NPP results were evaluated in this study using flux estimates from eddy-correlation analysis, obtained from AmeriFlux tower flux sites that could meet certain criteria for model comparisons. First, at least three complete years of site flux measurements were required to evaluate model predictions of interannual variations in CASA NPP fluxes. Second, winter (or dormant/dry) season NPP fluxes were required from a site to evaluate model predictions on a year-round basis. Third, tower sites had to be representative of the same (predominant) vegetation class setting in the global land cover data used as input to the CASA model.

For sites meeting all of these criteria, AmeriFlux data sets were obtained from the central data repository located at the Carbon Dioxide Information Analysis Center (CDIAC; http:// public.ornl.gov/ameriflux/dataproducts.shtml). Level 4 AmeriFlux records contained gapfilled and ustar filtered records, complete with calculated gross productivity and total ecosystem respiration terms on varying time intervals including hourly, daily, weekly, and monthly with flags for the quality of the original and gap-filled data. NPP fluxes were computed from Level 4 estimates of gross primary production (GPP) by adjustment within an uncertainty range of $40-50 \%$ of annual GPP carbon flux for temperate ecosystems 
Fig. 1 Comparison of observed NPP ( $n=1927$; Olson et al., 1997) to predicted annual values from the CASA model, driven separately by a MODIS-EVI and b MODIS-FPAR monthly inputs for the year 2001. The 1:1 regression line on each graph is shown, along with the linear correlation coefficient for the best fit to that 1:1 line

(Waring et al., 1998; Zhang et al., 2009) and $30 \%$ GPP in tropical forest ecosystems (Box 2004). The uncertainties in the ratio of tower-measured GPP to NPP may be even greater when monthly climate patterns are considered, although there are no published studies available that address this seasonal variation factor for numerous tower sites.

\section{Results}

\subsection{CASA model validation}

For this latest CASA model application, a comparison of observed NPP $(n=1927)$ from field based measurements to predicted annual values from the CASA model was made to provide validation of terrestrial NPP predictions across all ecosystem types. Observed NPP values were compiled for the Ecosystem Model-Data Intercomparison (EMDI) activity by the Global Primary Productivity Data Initiative (GPPDI) working groups of the International Geosphere Biosphere Program Data and Information System (IGBP-DIS; Olson et al., 1997). Monthly MODIS EVI inputs resulted in a highly significant correlation $\left(R^{2}=0.90\right)$ and a close 1:1 match of observed to CASA predicted NPP values, with the year 2001 selected as an example (Fig. 1).

In this comparison to observed NPP, the CASA model was also tested for sensitivity to the vegetation index monthly time series as well by driving the NPP algorithm separately with either MODIS-EVI or MODIS-FPAR monthly inputs, holding climate inputs constant. A lower level of saturation in the low-to-medium range of plant production estimated from CASA modeling with EVI inputs compared to FPAR inputs was discovered by comparison of the two scatter plots over the range of annual NPP from 100 to $300 \mathrm{gC} \mathrm{m}^{-2} \mathrm{yr}^{-1}$ (Fig. 1). Not only did EVI result in less overall scatter in the predicted versus observed plot (i.e., $R^{2}=0.81$ using MODIS FPAR inputs), the match to observed NPP in the high global range (of greater than $1000 \mathrm{gC} \mathrm{m}^{-2} \mathrm{yr}^{-1}$ ) was markedly more consistent with EVI compared to MODIS FPAR inputs.

CASA NPP using EVI inputs was next compared across the tropical forest zones to a literature review of NPP estimates by Clark et al. (2001) from old-growth tropical forest study sites that attempted to create a consistent data set on NPP for these primary (undisturbed) ecosystems. Because NPP is composed of both aboveground and belowground forest production, upper and lower bounds around total NPP were reported by Clark et al. (2001) expressly to serve as benchmarks for validating biogeochemical models for this biome. The results of this compilation showed $58 \%$ (22 out of 38$)$ of sites estimated with mean annual NPP lower than $1000 \mathrm{gC} \mathrm{m}^{-2} \mathrm{yr}^{-1}$, and another $26 \%$ (10 sites) were estimated with mean annual NPP lower than $1200 \mathrm{gC} \mathrm{m}^{-2} \mathrm{yr}^{-1}$ (Fig. 2). The comparison with the distribution of CASA NPP across the tropical forest zones indicated that large tracts $\left(>6 \mathrm{~km}^{2}\right.$ ) of undisturbed rainforest with annual NPP higher than $1000 \mathrm{gC} \mathrm{m}^{-2} \mathrm{yr}^{-1}$ (10 tons $\mathrm{C} \mathrm{ha}{ }^{-1}$ ) were nearly undetectable at the global scale. Despite the fact that hundreds of CASA annual NPP values of greater than $1000 \mathrm{gC} \mathrm{m}^{-2} \mathrm{yr}^{-1}$ were predicted at isolated locations across all tropical forest regions of the world (indicating that the model has no built-in upper limit for NPP in its formulation), these high rainforest NPP 
a

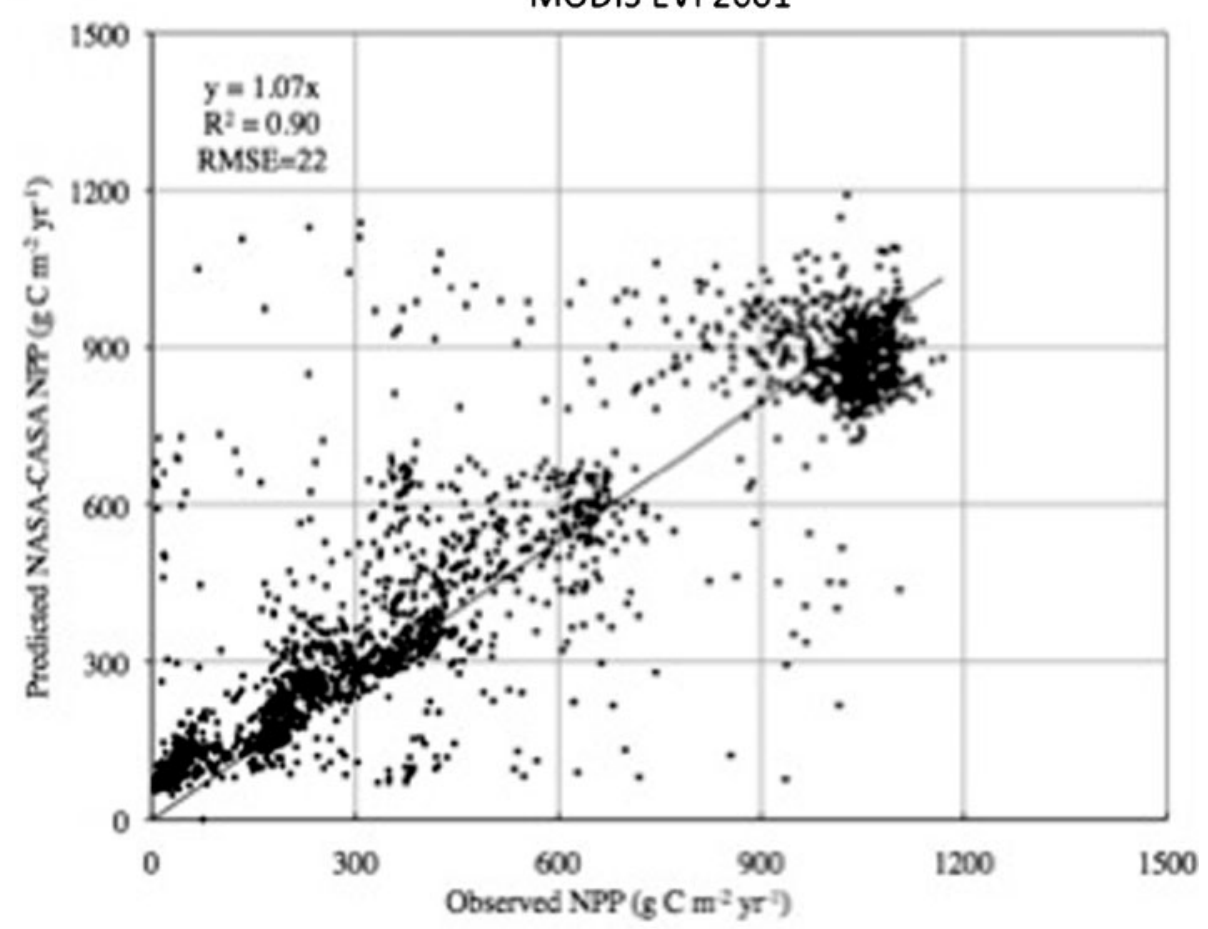

b

MODIS FPAR 2001

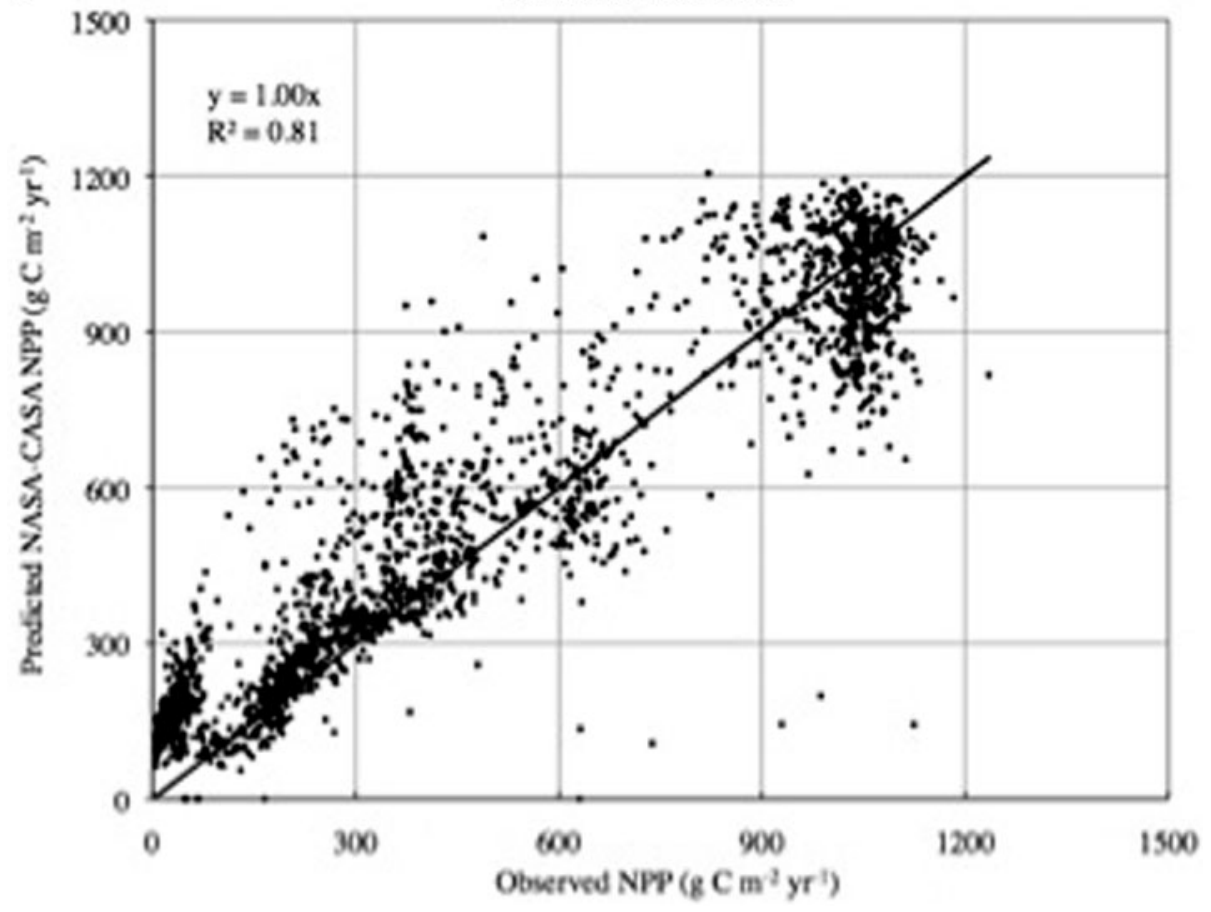


Fig. 2 Frequency distribution of annual NPP from a 38 old-growth tropical forest measurement sites compiled by Clark et al. (2001), and $\mathbf{b}$ tropical forest pixels $(n=6620)$ in the CASA model $0.5^{\circ}$ latitude/longitude global grid a
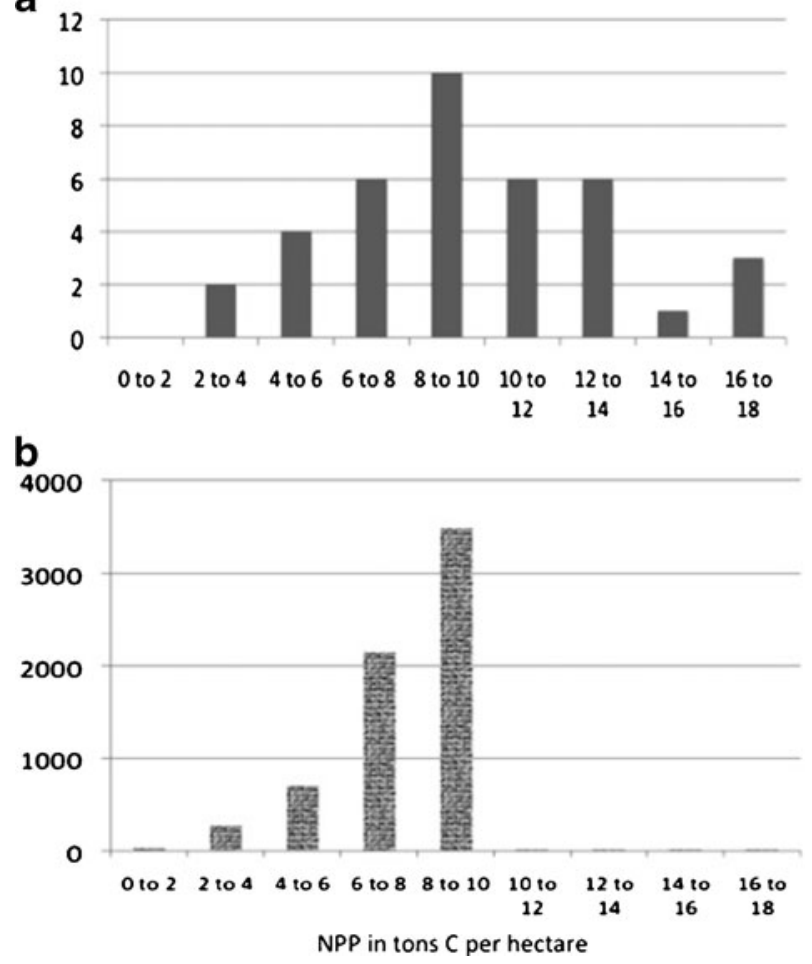

cases (as reported by Clark et al., 2001) were extreme outliers in the global model distribution and hence do not appear as significant totals in Fig. 2.

By way of additional model validation in the tropical zone, comparison of CASA seasonal NPP against measured totals from the Large-scale Biosphere-Atmosphere Experiment in Amazonia (LBA) showed close agreement at the Tapajos (Pará) forest experimental site (Potter et al., 2009). At the ZF2 Manaus forest site, Chambers et al. (2004) directly measured respiration rates from live leaf, live wood, and forest soil surfaces to derive an indirect NPP flux estimate of $900 \mathrm{~g}$ $\mathrm{C} \mathrm{m}^{-2} \mathrm{yr}^{-1}$. Annual NPP from CASA for this general area $\left(2.5^{\circ} \mathrm{S}\right.$ lat, $60{ }^{\circ} \mathrm{W}$ lon $)$ around Manaus in Brazil varied between 782 and $871 \mathrm{gC} \mathrm{m}^{-2} \mathrm{yr}^{-1}$ between 2000 and 2004.

Seasonal validation of CASA monthly NPP predictions from the MOD13C2 EVI data values closest to the AmeriFlux tower location was conducted by comparison to eddycorrelation monthly estimates of the corresponding NPP fluxes. It should be noted that the monthly MODIS EVI values in practically every grid cell of the global CASA model will be influenced by periodic land cover disturbances and areas of sparse vegetation cover, including development, roads, water bodies, and other natural features. It was expected, therefore, that CASA model NPP flux predictions would be systematically lower than tower measurements of these carbon fluxes, since tower footprints tend to be far less affected by wildfire and other disturbances, compared for instance to the surrounding MODIS grid cell area in which they are located.

A total of eight Ameriflux tower sites were found to meet the criteria cited in the methods section above for comparison to CASA model NPP predictions (Fig. 3). CASA model predictions closely followed the seasonal timing of Ameriflux tower measurements at each site, with a linear regression correlation coefficient of $R^{2}=0.77$ for all sites combined 

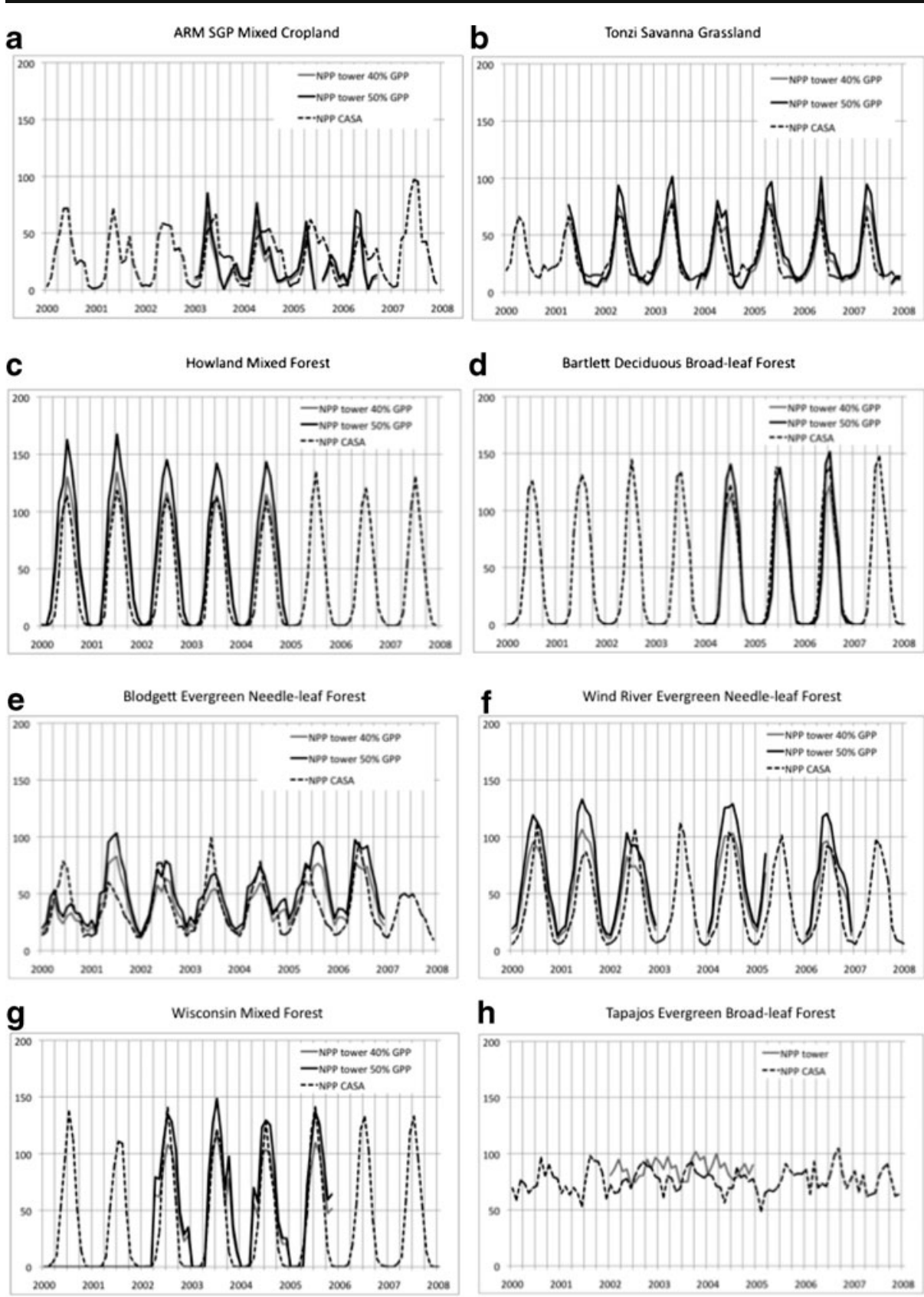

Fig. 3 Comparison of CASA monthly NPP to Ameriflux measurements derived from eddy-correlation estimates of the corresponding monthly NPP fluxes. Ameriflux NPP fluxes were plotted within an uncertainty range of $40 \%$ to $50 \%$ of GPP carbon flux

(Fig. 4). As expected, CASA predicted NPP underestimated by a modest level of $7 \%$ compared to all the monthly NPP measured from the Ameriflux towers (at the setting of $40 \%$ annual GPP carbon flux). 
Fig. 4 Scatter plot of Ameriflux tower estimates of monthly NPP and CASA predicted NPP values for the same months

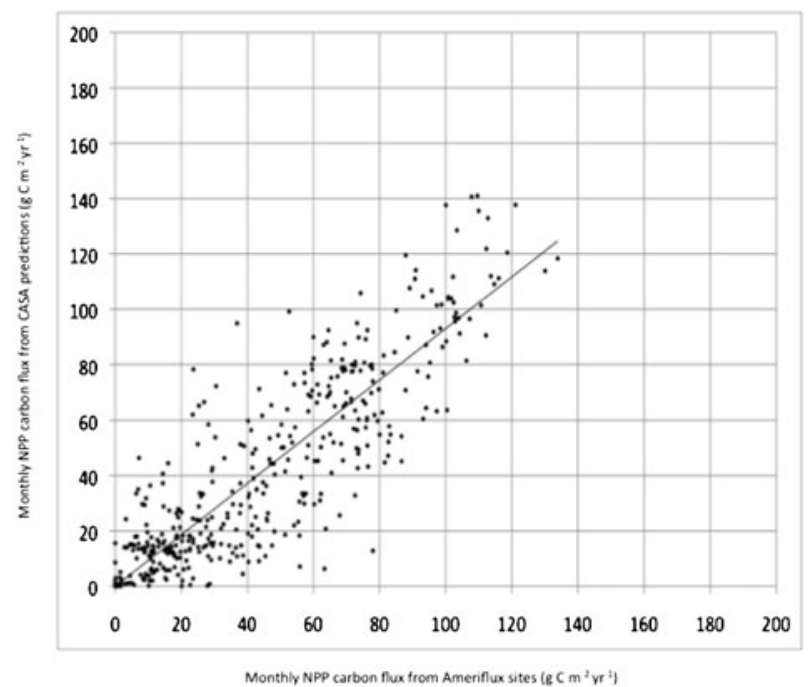

\subsection{Predicted global NPP patterns}

Predicted terrestrial NPP for the globe in 2009 was $50.05 \mathrm{Pg} \mathrm{C}$, a total carbon flux in the middle of the range of previous vegetation NPP predictions of between 44 and $66 \mathrm{Pg} \mathrm{C}$ per year for the period 1982-1998 (Cramer et al., 1999). We estimate that global terrestrial NPP increased by $+0.14 \mathrm{Pg} \mathrm{C}$ over the time period of 2000 to 2009 , due almost entirely to a strong upward trend in the Northern Hemisphere (Fig. 5). Annual NPP was predicted to have increased between the years 2000 and 2007 in the regions of high-latitude $\left(>50^{\circ} \mathrm{N}\right)$ North America and Eurasia, and also in South Asia, West and Central Africa, and the western Amazon (Figs. 5 and 6).

This upward trend in high-latitude NPP was controlled by a combination of rapidly warming temperatures from 2004 to 2005 (Zhao and Running, 2010), and by elevated MODIS EVI patterns over the same period. Periodic declines in regional NPP were

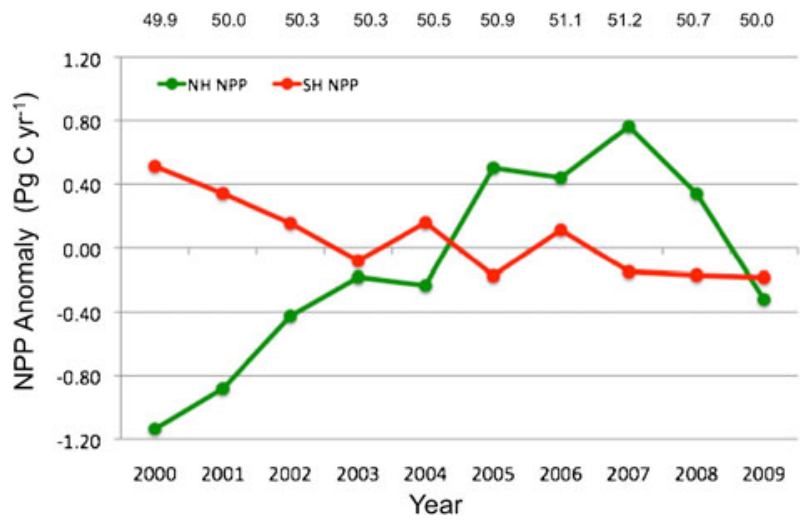

Fig. 5 Interannual variations from 2000 through 2009 in anomalies of annual total NPP for the CASA model for the Northern Hemisphere (NH-green circles) and the Southern Hemisphere ( $\mathrm{SH}$-red circles). Global

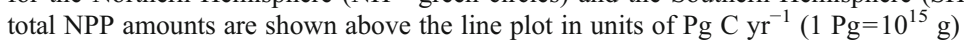




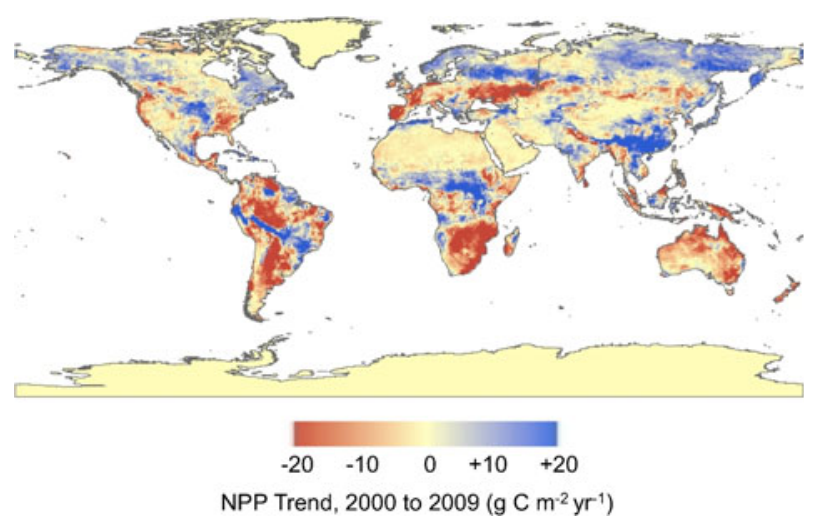

Fig. 6 Spatial pattern of terrestrial NPP linear trends from 2000 through 2009

predicted for the southern Untied States, the southern Amazon, western Europe, southern and eastern Africa, and Australia (Fig. 7); the timing of negative NPP anomalies in each of these regions was associated with severe droughts and, in some cases, extreme heat waves (World Meteorological Organization, 2001 2009).

When global NPP predictions were broken down into $30^{\circ}$ latitude zones, monthly air temperature was found to be highly correlated $\left(R^{2}>0.9\right)$ with seasonal increases and decreases in NPP at latitudes between $30^{\circ} \mathrm{N}$ and $90^{\circ} \mathrm{N}$ (Table 1). Monthly precipitation was found to be more closely correlated $\left(R^{2}>0.8\right)$ with seasonal increases and decreases in NPP than was air temperature at latitudes between $30^{\circ} \mathrm{N}$ and $30^{\circ} \mathrm{S}$, whereas EVI was closely correlated $\left(R^{2}>0.7\right)$ with monthly NPP in all latitude zones. Correlations between monthly EVI anomalies (2000-2009) and predicted monthly NPP anomalies were significant in all latitude zones as well, which implies that, across latitiude zones, interannual NPP variations were most strongly controlled by EVI inputs, compared to short-term variations in air temperature or precipitation.

Nonetheless, there were many instances of severe drought affecting terrestrial NPP on local-to-regional scales across the globe during the period of 2000 to 2008, mainly in areas of the central North America, Africa, Brazil, and China (Fig. 7). Beginning with major droughts in Brazil, the Horn of Africa, the Middle East, Central and South Asia, and China in 2000 and 2001, these events were followed by most of North America, southern Africa, and Australia experiencing record low precipitation amounts in 2002, 2003, and 2004. Large areas of Europe, southern Africa, Brazil, and Paraguay were affected by severe droughts in 2005. From 2006 though 2008, much of the United States, eastern and southern Africa, China, and Australia experienced continued deficits of precipitation.

Drought in the Amazon basin approached unprecedented levels in 2009 (and into 2010; Lewis et al., 2011), and the impact on NPP was evident in the CASA model prediction of 2009 anomalies in excess of $-100 \mathrm{gC} \mathrm{m}^{-2} \mathrm{yr}^{-1}$ in the central and western portions of the basin (Fig. 7). This was seen in contrast to the impacts of the severe drought of 2005, which was predicted to have impacted tropical forest NPP (with anomalies on the order of $-20 \mathrm{gC}$ $\mathrm{m}^{-2} \mathrm{yr}^{-1}$ ) mainly in the eastern and in more isolated southwestern portions of the Brazilian Amazon.

A notable global difference of our CASA model estimates of NPP from those of previous terrestrial carbon studies (Cramer et al., 1999) was the magnitude of tropical forest NPP. Whereas these previously cited estimates of annual NPP across rainforest study sites that were largely protected from human disturbance have commonly exceeded $900 \mathrm{gC} \mathrm{m}^{-2} \mathrm{yr}^{-1}$ 
a
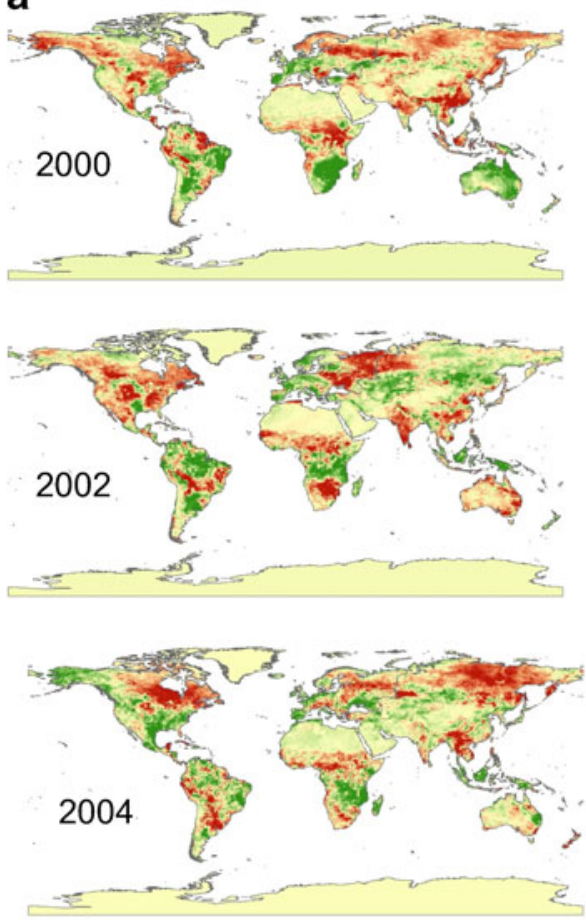

\section{b}
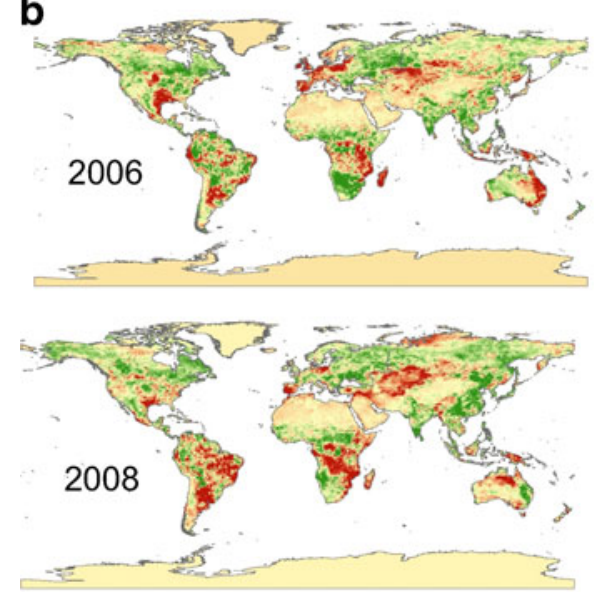
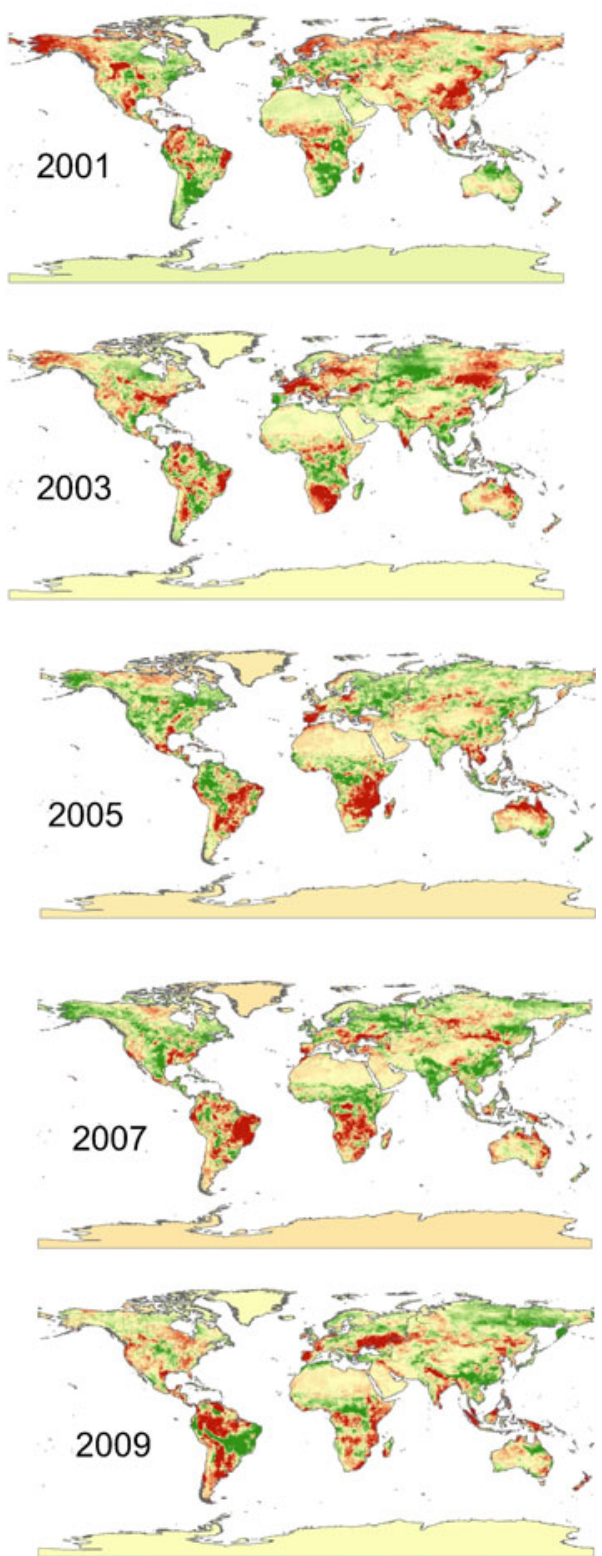

\section{$\begin{array}{lllllll}-120 & -80 & -40 & 0 & +40 & +80 & +120\end{array}$ \\ NPP Anomaly $\left(\mathrm{g} \mathrm{C} \mathrm{m}^{-2} \mathrm{yr}^{-1}\right)$}

(Clark et al., 2001), our CASA model for 2009 estimated an average NPP of $840 \mathrm{gC}$ $\mathrm{m}^{-2} \mathrm{yr}^{-1}$ in the South American tropical region, an average of $805 \mathrm{gC} \mathrm{m}^{-2} \mathrm{yr}^{-1}$ in the African tropical region, and an average of $847 \mathrm{gC} \mathrm{m}^{-2} \mathrm{yr}^{-1}$ in the South East Asian tropical 
Fig. 7 Global maps of annual NPP anomalies (2001-2009) derived from subtraction of the decadal mean NPP values from the CASA model. Extensive negative NPP anomalies in the following years were observed: 2001-2002 across the central Untied States, southern Africa, China, and eastern Brazil associated with severe drought in these regions; 2003-2004 across most of Europe and eastern Russia associated with extreme summer heat; 2005 across the southern Amazon and central Africa associated with severe drought, 2007-2009 across the southeastern United States, east Africa, and Australia associated with severe drought (World Meteorological Organization, 2001 2009)

region. Although hundreds of annual NPP values of greater than $1000 \mathrm{gC} \mathrm{m}^{-2} \mathrm{yr}^{-1}$ were estimated as well at isolated locations across all three tropical forest regions of the world, the impact of deforestation and replacement of forests by lower production tropical agricultural systems has been widely captured by the MODIS EVI inputs to CASA since the year 2000.

Across the tropical rainforest zones, CASA NPP in 2009 totaled to $13.7 \mathrm{Pg} \mathrm{C} \mathrm{yr}^{-1}$, accounting for nearly one-third (27\%) of global terrestrial NPP. Of the three major tropical rainforest regions, South America $\left(80-43^{\circ} \mathrm{W}\right)$ accounted for $47 \%$ of the zonal NPP total, whereas Africa $\left(13.5-40^{\circ} \mathrm{E}\right)$ and Asia $\left(73.5-162.5^{\circ} \mathrm{E}\right)$ regions together accounted for $45 \%$ of the zonal NPP total (Table 2).

\section{Discussion}

The comparative sensitivity of MODIS EVI and FPAR results to the range of global measured NPP values (Fig. 1) confirms previous reports (Huete et al., 2002; Xiao et al., 2006; Colditz et al., 2007) that the global EVI time series has a higher dynamic response across the full range of vegetated cover, does not saturate in medium-to-high biomass areas, and is less susceptible to atmospheric interference, all in contrast to other vegetation indices used previously in the CASA model. The lower level of saturation of low-to-medium range plant production estimated from CASA modeling with MODIS EVI inputs (compared to MODIS FPAR inputs) resulted in lower annual NPP in any tropical zones where primary forest has become increasing mixed with degraded forest and converted agricultural land uses. This global trend of rainforest destruction has been reported at rates exceeding $2.3 \%$ of remaining humid forest cover between the years 2000 and 2005 (Hansen et al., 2008).

We note that the patterns in terrestrial NPP from CASA between the years 2000 and 2007 differed from the decreasing trend of $-0.51 \mathrm{Pg} C$ reported from the global MODIS NPP algorithm (hereafter abbreviated MNA; Zhao and Running, 2010; Running et al., 2004), which used satellite FPAR inputs and the same NCEP reanalysis data set as in the CASA model for climate inputs. On a regional basis, our model results also differed from the MNA for 2000-2009 (Zhao and Running, 2010), which reported that NPP in the tropical zones

Table 1 Non-linear correlations $\left(R^{2}\right)$ between zonal monthly NPP predicted by the CASA model and zonal monthly input parameters of surface air temperature (TMP), precipitation (PPT), and MODIS EVI values. Correlations between monthly anomalies (2000-2009) and predicted monthly NPP anomalies are shown in parentheses

\begin{tabular}{llll}
\hline Latitude Zone & TMP & PPT & EVI \\
\hline $90^{\circ}-60^{\circ} \mathrm{N}$ & $0.94(0.04)$ & $0.71(0.03)$ & $0.77(0.53)$ \\
$60^{\circ}-30^{\circ} \mathrm{N}$ & $0.95(0.12)$ & $0.71(0.01)$ & $0.88(0.61)$ \\
$30^{\circ}-0^{\circ} \mathrm{N}$ & $0.79(0.05)$ & $0.83(0.01)$ & $0.79(0.26)$ \\
$0^{\circ}-30^{\circ} \mathrm{S}$ & $0.70(0.14)$ & $0.93(0.02)$ & $0.73(0.51)$ \\
\hline
\end{tabular}


Table 2 Comparison of the tropical rainforest zone NPP (Pg C) totals in 2009 between the CASA model and the MNA (Zhao and Running, 2010)

\begin{tabular}{lcc}
\hline Continent & CASA & MNA \\
\hline Africa & 2.45 & 2.87 \\
Asia & 3.74 & 3.81 \\
South America & 6.53 & 7.52 \\
Total Rainforest & 13.7 & 15.6 \\
\hline
\end{tabular}

$\left(23.5^{\circ} \mathrm{S}\right.$ to $\left.23.5^{\circ} \mathrm{N}\right)$ explained $93 \%$ of variations in the global NPP. In contrast, with CASA we found that NPP in the tropical zones explained only 50-60\% of variations in the global NPP, whereas NPP in the latitude zone between $30^{\circ} \mathrm{N}$ and $60^{\circ} \mathrm{N}$ could explain between $40 \%$ and $50 \%$ of variations in the global NPP.

Notwithstanding the difference in the global trend of NPP between CASA and the predictions from the MNA, the overall patterns of interannual variations in Northern and Southern Hemisphere NPP anomalies were similar between the two model results. NPP anomalies in the Northern Hemisphere were negative from 2000 to 2003 and then became strongly positive from 2004 to 2008 , closely following the $0.1^{\circ} \mathrm{yr}^{-1}$ surface-warming trend in the model input data. NPP anomalies in the Southern Hemisphere were positive from 2000 to 2003 and then turned negative between 2004 and 2008, with 2005 being the most strongly negative anomaly year.

The main difference between the two model predictions was the magnitude of NPP interannual anomalies in the Southern Hemisphere, with those from the MNA estimated to exceed those from the CASA model by a factor of more than ten in the years 2000, 2001, and 2005. We note that the MNA-estimated cumulative loss of 4 Pg C NPP in the Southern Hemisphere annual NPP between the years 2000 and 2005 is roughly equivalent to total yearly NPP over all the tropical forests of Asia (Table 2), and exceeds by a factor of two the estimated global emission of carbon to the atmosphere from tropical forest fires during the strong El Nino droughts of 1997-1998 (van der Werf et al., 2004). Criticism of Zhao and Running's (2010) results by Medlyn (2011) and Samanta et al. (2011) include remarks that sensitivity analysis, evaluation of bias introduced by gap filling of satellite data, and generally weak correlations with field observations would result in the reported negative global trend in NPP being insignificant.

The differences in these recent model results underscore the problem of how remotely sensed models for terrestrial NPP should account for environment stresses, especially those that affect plant autotrophic respiration. For instance, previous studies (Nepstad et al., 1994; Saleska et al., 2003; Xiao et al., 2003; Ichii et al., 2007) have concluded that the setting of proper rooting depths is important to simulating primary production seasonality in tropical forests. The CASA model specifies deep-rooting for prolonged tropical forest access to stored soil water and relies on observed changes in MODIS EVI to track moisture stress effects globally. CASA does not account for the additional costs of autotrophic respiration in the manner of the MNA. NPP models such as the MNA do not consider rooting depth, but rely on nonlinear functions of increasing temperature to estimate production responses to water scarcity. Such functions can amplify heat stress effects greatly in the low-latitude zones, since the same increase in air temperature at higher temperature bases in the tropics will increase autotrophic respiration costs for NPP to greater degree than in the high latitude zones (Zhao and Running, 2010).

The different approaches to modeling environment controls on NPP cited in this paper call attention to the need for additional measurements of terrestrial production in forested landscapes of the world that have been impacted by deforestation and conversion to lower 
production ecosystems. Terrestrial biosphere representations at coarse (1-km or greater) geographic resolution cannot readily capture the vast areas of mixed non-forest uses within the predominant land cover setting, and instead tend to treat tropical forest cover as if there were continuous stands of intact trees with high potential respiration costs to primary production.

The reality is that forests are comprised of diverse mosaics of vegetation types with widely varying photosynthetic and respiratory physiologies. Although the impacts of warming-associated drought must not be overlooked as a periodic driver of carbon losses from ecosystems to the atmosphere, forests of the world that have already been widely converted and degraded by human use require far more field research to understand how to best represent these regions in global NPP models.

Acknowledgments This work was supported by the Planetary Skin Institute and grants from NASA programs in Carbon Cycle Science and the Large-scale Biosphere-Atmosphere Experiment in Amazonia (LBA),

Open Access This article is distributed under the terms of the Creative Commons Attribution License which permits any use, distribution, and reproduction in any medium, provided the original author(s) and the source are credited.

\section{References}

Behrenfeld MJ, Randerson JT, McClain CR, Feldma GC, Los SQ, Tucker CI, Falkowski PG, Field CB, Frouin R, Esaias WE, Kolber DD, Pollack NH (2001) Biospheric primary production during an ENSO transition. Science 291:2594-2597

Box EO (2004) Gross production, respiration and biosphere $\mathrm{CO}_{2}$ fluxes under global warming. Trop Ecol 45 (1):13-29

Chambers JQ, Tribuzy ES, Toledo LC, Crispim BF, Higuchi N, dos Santos J, Araujo AC, Kruijt B, Nobre AD, Trumbore SE (2004) Respiration from a tropical forest ecosystem: Partitioning of sources and low carbon use efficiency. Ecol Appl 14:S72-S88

Clark DA, Brown S, Kicklighter DW, Chambers JQ, Thomlinson JR, Ni J, Holland EA (2001) Net primary production in tropical forests: an evaluation and synthesis of existing field data. Ecol Appl 11:371-384

Colditz RR, Conrad C, Wehrmann T, Schmidt M, Dech SW (2007) Analysis of the quality of collection 4 and 5 vegetation index time series from MODIS. ISPRS Spatial Data Quality Symposium. Enschede. CRC press, The Netherlands

Cramer W, Kicklighter DW, Bondeau A, Iii B, Moore, Churkina G, Nemry B, Ruimy A, Schloss AL (1999) Comparing global models of terrestrial net primary productivity (NPP): overview and key results. Glob Chang Biol 5:1-15

Goetz SJ, Prince SD (1998) Variability in light utilization and net primary production in boreal forest stands. Can J For Res 28:375-389

Hansen MC, Roy D, Lindquist E, Justice CO, Altstaat A (2008) A method for integrating MODIS and Landsat data for systematic monitoring of forest cover and change in the Congo Basin. Remote Sens Environ 112:2495-2513

Huete A, Didan K, Miura T, Rodriguez E (2002) Overview of the radiometric and biophysical performance of the MODIS vegetation indices. Remote Sens Environ 83:195-213

Huete AR, Didan K, Shimabukuro YE, Ratana P, Saleska SR, Hutyra LR, Fitzjarrald D, Yang W, Nemani RR, and Myneni R (2006) Amazon rainforests green-up with sunlight in dry season, Geophys. Res. Lett., 33, L 06405, doi:10.1029/2005GL025583

Ichii K, Hashimoto H, White MA, Potter C, Hutyra LR, Huete AR, Myneni RB, Nemani RR (2007) Constraining rooting depths in tropical rainforests using satellite data and ecosystem modeling for accurate simulation of GPP seasonality. Glob Chang Biol 13:67-77

Jönsson P, Eklundh L (2004) TIMESAT: A program for analysing time-series of satellite sensor data. Comput Geosci 30:833

Lewis SL, Brando PM, Phillips OL, van der Heijden GMF, Nepstad D (2011) The 2010, Amazon drought. Science 331(6017):554. doi:10.1126/science. 1200807 
Malmström CM, Thompson MV, Juday GP, Los SO, Randerson JT, Field CB (1997) Interannual variation in global scale net primary production: Testing model estimates. Global Biogeochem Cycles 11:367-392

Medlyn BE (2011) Comment on "Drought-Induced reduction in Global Terrestrial Net Primary Production from 2000 Through 2009”. Science 333:1093

Monteith JL (1972) Solar radiation and productivity in tropical ecosystems. J Appl Ecol 9:747-766

Nemani RR, Running SW (1989) Testing a theoretical climate-soil-leaf area hydrologic equilibrium of forests using satellite data and ecosystem simulation. Agric For Met 44:245-260

Nemani RR, Keeling CD, Hashimoto H, Jolly WM, Piper SC, Tucker CJ, Myneni RB, Running SW (2003) Climate driven increases in global terrestrial net primary production from 1982 to 1999 . Science 300:1560-1563

Nepstad DC et al (1994) The role of deep roots in the hydrological and carbon cycles of Amazonian forests and pastures. Nature 372:666-669

Olson RJ, Scurlock JMO, Cramer W, Parton WJ, and Prince SD (1997) From Sparse Field Observations to a Consistent Global Dataset on Net Primary Production. IGBP-DIS Working Paper No. 16, IGBP-DIS, Toulouse, France, 1997

Potter C, Klooster S, Huete A, Genovese V, Bustamante M, Ferreira LG, Cosme de Oliveira R Jr, Zepp R (2009) Terrestrial carbon sinks in the Brazilian Amazon and Cerrado region predicted from MODIS satellite data and ecosystem modeling. Biogeosciences 6:1-23

Potter CS (1999) Terrestrial biomass and the effects of deforestation on the global carbon cycle. BioScience 49:769-778

Potter C, Klooster S, Myneni R, Genovese V, Tan P, Kumar V (2003) Continental scale comparisons of terrestrial carbon sinks estimated from satellite data and ecosystem modeling 1982-98. Glob Planet Chang 39:201-213

Potter CS, Randerson JT, Field CB, Matson PA, Vitousek PM, Mooney HA, Klooster SA (1993) Terrestrial ecosystem production: A process model based on global satellite and surface data, Global Biogeochem. Cycles 7:811-841

Priestly CHB, Taylor RJ (1972) On the assessment of surface heat flux and evaporation using large-scale parameters. Mont Weather Rev 100:81-92

Running SW, Nemani RR, Heinsch FA, Zhao M, Reeves M, Hashimoto H (2004) A continuous satellitederived measure of global terrestrial primary production. BioScience 54:547-560

Running SW, Nemani RR (1998) Relating seasonal patterns of the AVHRR vegetation index to simulated photosynthesis and transpiration of forests in different climates. Remote Sens Environ 24:347-367

Saleska SR, Miller SD, Matross DM, Goulden ML, Wofsy SC, da Rocha H, de Camargo PB, Crill PM, Daube BC, Freitas C, Hutyra L, Keller M, Kirchhoff V, Menton M, Munger JW, Pyle EH, Rice AH, Silva H (2003) Carbon in Amazon forests: unexpected seasonal fluxes and disturbance-induced losses. Science 302:1554-1557

Samanta A, Costa MH, Nunes EL, Vieira SA, Xu L, Myneni RB (2011) Comment on "Drought-Induced reduction in Global Terrestrial Net Primary Production from 2000 Through 2009”. Science 333:1093

Sellers PJ, Tucker CJ, Collatz GJ, Los SO, Justice CO, Dazlich DA, Randall DA (1994) A global 1×1 NDVI data set for climate studies. Part 2: the generation of global fields of terrestrial biophysical parameters from the NDVI. Int J Remote Sens 15:3519-3545

van der Werf GR, Randerson JT, Collatz GJ, Giglio L, Kasibhatla PS, Arellano A, Olsen SC, Kasischke ES (2004) Continental-scale partitioning of fire emissions during the 97/98 El Nino. Science 303:73-76

Waring RH, Landsberg JJ, Williams M (1998) Net primary production of forests: a constant fraction of gross primary production? Tree Physiol 18(2):129-134

World Meteorological Organization, WMO Statement on the Status of the Global Climate in 2001, WMO\#670, December 18, 2001

Xiao X, Hagen S, Zhang Q, Keller M, Moore B III (2006) Detecting leaf phenology of seasonally moist tropical forests in South America with multi-temporal MODIS images. Remote Sens Environ 103:465-473

Xiao X, Zhang Q, Saleska SR, Hutyra L, Camargo P, Wofsy S, Frolking S, Boles S, Keller M, Moore B III (2003) Satellite-based modeling of gross primary production in a seasonally moist tropical evergreen forest. 2005. Remote Sens Environ 94:105-122

Zhang Y, Xu M, Chen H, Adams J (2009) Global pattern of NPP to GPP ratio derived from MODIS data: effects of ecosystem type, geographical location and climate. Global Ecol Biogeogr 18:280-290

Zhao M, and Running SW (2010) Drought-induced reduction in global terrestrial net primary production from 2000 through 2009, Science, 329, 940-943. Supporting Online Material at http://www.sciencemag.org/ content/329/5994/940/suppl/DC1

Zhao M, Running SW (2011) Response to Comments on "Drought-Induced Reduction in Global Terrestrial Net Primary Production from 2000 Through 2009”. Science 333(1093):10.1126/science.1199169 